\title{
Effects of ovariectomy and oestradiol-17 $\beta$ replacement on brain tyrosine hydroxylase in the catfish Heteropneustes fossilis: changes in in vivo activity and kinetic parameters
}

\author{
R Chaube and K P Joy \\ Department of Zoology, Banaras Hindu University, Varanasi 221005, India \\ (Requests for offprints should be addressed to K P Joy; Email: kpjoy@banaras.ernet.in)
}

\begin{abstract}
In Heteropneustes fossilis, ovariectomy inhibited in vivo brain (hypothalamus-pituitary, telencephalon and medulla oblongata) tyrosine hydroxylase (TH) activity with significant effects in weeks $2,3,4$ and 5 of the gonadal resting phase and in weeks 3,4 and 5 of the prespawning phase $\left(P<0 \cdot 05\right.$, Tukey's test). Oestradiol-17 $\beta \quad\left(\mathrm{OE}_{2}\right)$ replacement in 3-week ovariectomised fish produced biphasic responses in both seasons; the low dosages of 0.05 and $0.5 \mu \mathrm{g} / \mathrm{g}$ body weight (BW) elevated $\mathrm{TH}$ activity, whereas the high dosages of 1.0 and $2.0 \mu \mathrm{g} / \mathrm{g} \mathrm{BW}$ decreased it. The magnitude of the inhibition was higher in the resting phase than in the prespawning phase. The inhibitory effect of ovariectomy may be produced by elevating the apparent $K_{\mathrm{m}}$ values (decreased affinity) of the enzyme for both L-tyrosine (substrate) and dimethyltetrahydropteridine (cofactor) and consequently decreasing the $\mathrm{V}_{\max }$. Significant changes $(P<0 \cdot 05)$ in both these parameters were noticed but showed minor differences
\end{abstract}

with regard to the length of ovariectomy, season or brain regions. The biphasic effects of $\mathrm{OE}_{2}$ replacement on $\mathrm{TH}$ activity seemed to be produced by differential effects on apparent $K_{\mathrm{m}}$ and $\mathrm{V}_{\max }$. The stimulatory effect of the low dosages of $\mathrm{OE}_{2}$ coincides with a decrease in the apparent $K_{\mathrm{m}}$ values (increased affinity) for both substrate and cofactor and an increase in the $\mathrm{V}_{\max }$ of the enzyme. The inhibitory effect of the high dosages of $\mathrm{OE}_{2}$ correlated with an increase in the apparent $K_{\mathrm{m}}$ values (decreased affinity) for both substrate and cofactor, and a decrease in the $\mathrm{V}_{\max }$ compared with the lower dosage groups. The results strongly suggested that $\mathrm{OE}_{2}$ can modulate brain catecholaminergic activity at the level of tyrosine hydroxylation which, in turn, may alter gonadotrophin secretion. $\mathrm{OE}_{2}$ may elicit biphasic effects by differentially altering the enzyme affinity towards the substrate and cofactor.

Journal of Endocrinology (2002) 175, 329-342

\section{Introduction}

In teleosts, neuroanatomical studies have demonstrated an extensive distribution of monoamines in the brain with a predominant concentration of neuronal perikarya in the hypothalamus (Hornby \& Piekut 1990, Ekstrom et al. 1995). A unique feature of this distribution is that the hypothalamic aminergic system forms an important component of the hypothalamo-hypophysial system, the aminergic fibres making direct or indirect contacts with secretory cells in the pituitary. The functional significance of the aminergic innervation has been investigated in a number of teleosts and indicates its strong involvement in the regulation of various pituitary hormones (Olivereau \& Olivereau 1999a,b). In the regulation of gonadotrophin (GTH) secretion, it has been well documented that dopamine (DA) inhibits and noradrenaline (NA) stimulates spontaneous and/or gonadotrophin-releasing hormoneinduced GTH-II (luteinizing hormone; LH) release (Schulz et al. 1995, Peter \& Yu 1997, Joy 1999). Catecho-

lamine (CA) involvement is also indictated by significant variations in activity during the reproductive cycle (Guerrero et al. 1990, Senthilkumaran \& Joy 1995, Hernandez-Rauda et al. 1999). In Heteropneustes fossilis, the hypothalamic catecholamines DA, NA and adrenaline show differential activity during the reproductive cycle; DA which dominates in the gonadal quiescent phase is hydroxylated to yield NA which predominates in the early recrudescent phase (preparatory and prespawning phases) and the latter (NA) is N-methylated to adrenaline which dominates the late recrudescent (spawning) phase (Senthilkumaran \& Joy 1995). The activity of the CA-synthesising enzymes, DA- $\beta$-hydroxylase $(\mathrm{D} \beta \mathrm{H})$ and phenylethanolamine-N-methyltransferase (PNMT), closely parallels the CA seasonal pattern and is stimulated by long photoperiods and/or high temperature (Senthilkumaran \& Joy 1995), implying environmental modulation of LH secretion through the CAs.

Among endogenous factors, gonadal steroids exert positive or negative feedback control on LH secretion in 
teleosts (Goos et al. 1999). In the feedback control, it has been shown that the steroids interact at different enzyme-catalysed steps in CA synthesis and degradation, such as oxidative deamination (including serotonin deamination) by monoamine oxidase (Senthilkumaran \& Joy 1994, 1995), O-methylation of CA by catechol-Omethyltransferase (Joy \& Senthilkumaran 1998), $\beta$-hydroxylation of $\mathrm{DA}$ by $\mathrm{D} \beta \mathrm{H}$ and $\mathrm{N}$-methylation of NA by PNMT (Senthilkumaran \& Joy 1995). In our laboratory, we used ovariectomised and oestradiol-17 $\beta$ $\left(\mathrm{OE}_{2}\right)$-replaced Heteropneustes fossilis as experimental models to study the steroid-monoamine interaction and feedback regulation of LH secretion (Senthilkumaran \& Joy 1994, 1995).

Tyrosine hydroxylase (TH) is the first and rate-limiting enzyme in CA synthesis (Nagatsu et al. 1964). Because of these features, as well as its multi-factorial regulation, including end-product feedback inhibition (Ames et al. 1978, Zigmond et al. 1989), measuring TH activity is a more sensitive index to assess CA neuronal activity than measuring the amines per se. A functional interaction between gonadal steroids and $\mathrm{TH}$ activity (vis-a-vis $\mathrm{CA}$ ) has been reported in mammals in the context of LH and prolactin regulation (Beattie et al. 1972, Beattie \& Soyka 1973, Babu \& Vijayan 1984, Blum et al. 1987, Gonzales et al. 1989). In teleosts, studies on TH have been largely confined to its use as a marker enzyme to demonstrate the neuroanatomical distribution of the CA system (Hornby \& Piekut 1990), the quantitative distribution of TH activity in different brain regions (Saligaut et al. 1993, Linard et al. 1996a) and cDNA cloning and sequencing of $\mathrm{TH}$ in rainbow trout (Linard et al. 1998). In rainbow trout, oestrogen receptor-binding neurones are mostly TH positive in the preoptic area which implies that oestrogen feedback sites are located on CA(DA)-ergic neurons (Linard et al. 1996b). Gonadectomy inhibits mRNA levels in $\mathrm{TH}$ neurones and $\mathrm{OE}_{2}$ treatment partially reverses the effect (Vetillard et al. 1999). We have recently shown significant seasonal, sex and brain regional differences in TH with high activity in the gonadal recrudescent phase and stimulation of enzyme activity on exposure to long photoperiods and high temperature (Chaube \& Joy $2002 a, b)$. Detailed experimental studies on oestrogen regulation of $\mathrm{TH}$ activity are lacking in teleosts.

In the present study, we have demonstrated ovariectomy and $\mathrm{OE}_{2}$ replacement-induced changes in $\mathrm{TH}$ activity and kinetics in different brain regions in gonadal quiescent and recrudescent phases.

\section{Materials and Methods}

\section{Chemicals}

Catalase, L-tyrosine, $\mathrm{OE}_{2}$, 6-7-dimethyl-2-amino-4hydroxy-5,6,7,8 tetrahydropteridine $\left(\mathrm{DMPH}_{4}\right)$, bovine serum albumin (BSA), Sephadex G-25 and 3-amino- benzoic acid ethylester (MS222) were purchased from Sigma Chemicals, St Louis, MO, USA. Sodium molybdate, 2-mercaptoethanol, sodium nitrite and Folin-Ciocalteu reagent were purchased from E-Merck (Mumbai, India). Other reagent chemicals were purchased from Hi-media or BDH (Mumbai, India).

\section{Collection and acclimatisation of fish}

Heteropneustes fossilis is a freshwater air-breathing catfish whose reproductive cycle can be divided into five phases: resting (November-January), preparatory (FebruaryApril), prespawning (May-June), spawning (July-August) and post-spawning (September-October) phases. Fish were collected from local fish markets in Varanasi (resting and prespawning phases). They were maintained in flow-through aquarium tanks under a normal photoperiod and ambient temperature (resting phase: $10.5 \mathrm{~h}$ light: $13.5 \mathrm{~h}$ darkness, $18 \pm 2{ }^{\circ} \mathrm{C}$; prespawning phase: $12.5 \mathrm{~h}$ light: $11.5 \mathrm{~h}$ darkness, $28 \pm 2{ }^{\circ} \mathrm{C}$ ). They were fed minced goat liver daily. After 15 days of acclimatisation, the following experiments were conducted.

\section{Ovariectomy}

About 120 acclimated fish were ovariectomised and 100 fish were sham-ovariectomised in the resting (second week of December) and prespawning (second week of May) phases of the reproductive cycle. The fish were anaesthetised with MS222 (100 mg/250 ml distilled water) by spraying it over the gills. A $4 \mathrm{~cm}$ long midventral incision was made anterior to the urogenital pore to expose the paired ovary. The ovaries were carefully detached from the peritoneal covering and removed. The cut end of the oviduct was cauterised with a hot needle to prevent regeneration and the incision sutured. The fish were treated with benzanthine penicillin (16 $000 \mathrm{IU} / 1)$ for 3-5 days to prevent skin infection. For sham-ovariectomy, all the above steps were followed except that the ovaries were not removed. The operated fish were maintained for 1, 2, 3, 4 and 5 weeks. Mortality was negligible $(<3 \%)$. Completeness of ovariectomy and regeneration of gonads, if any, were checked by examining the peritoneal cavity of the fish at the time of sampling. Only tissues from completely ovariectomised fish were used for enzyme assay.

\section{$\mathrm{OE}_{2}$ supplementation}

Five 3-week ovariectomised fish in both the resting and the prespawning phases were given $\mathrm{OE}_{2}$ intraperitoneally in dosages of $0 \cdot 05,0.5,1.0$ and $2 \cdot 0 \mu \mathrm{g} / \mathrm{g}$ body weight (BW) daily for 3 days. Five ovariectomised and five 


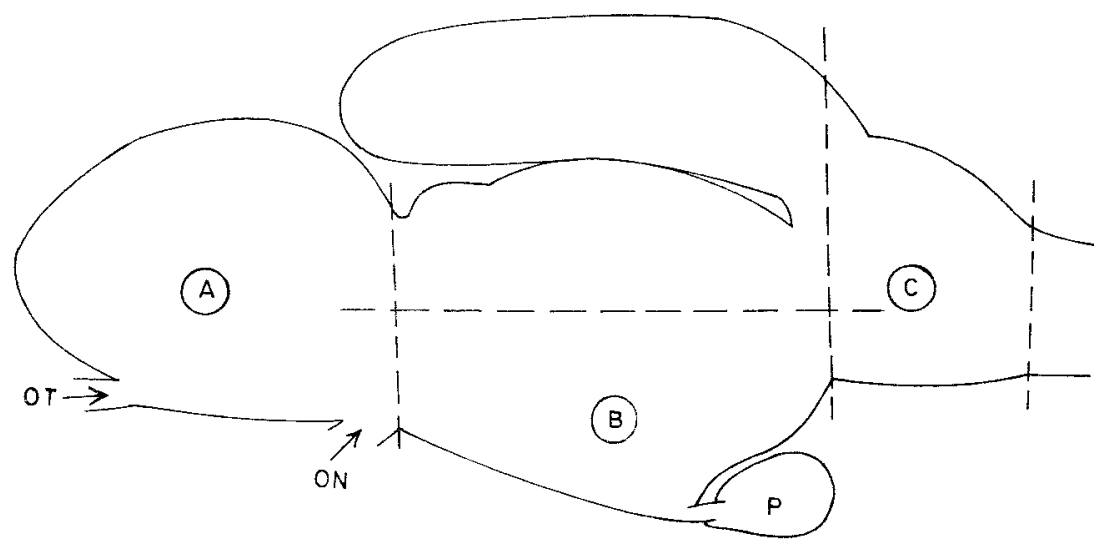

Figure 1 A diagrammatic representation (sagittal view) of the brain of Heteropneustes fossilis showing the plane of cuts to separate various regions used in the study.

A, telencephalon; B, hypothalamus; C, medulla oblongata; $\mathrm{P}$, pituitary; OT, olfactory tract; $\mathrm{ON}$, optic nerve.

sham-ovariectomised fish were given an equal volume $(0 \cdot 1 \mathrm{ml})$ of vehicle (propylene glycol) as controls.

\section{Tissue sampling and processing}

At the end of the experiments, the fish were killed by decapitation between 1100 and $1200 \mathrm{~h}$. Brains, along with the pituitary, were dissected out immediately on ice. Telencephalon (excluding olfactory tract and bulb) and hypothalamus along with pituitary and medulla oblongata were separated as shown in Fig. 1. The tissues were stored at $-70^{\circ} \mathrm{C}$. After $24 \mathrm{~h}$, the tissues were thawed and homogenised in $30 \mathrm{mM}$ sucrose containing $10 \mathrm{mM}$ Tris$\mathrm{HCl}$ buffer $(\mathrm{pH} 7 \cdot 3)$ in a Potter-Elvehjem homogeniser with a loose fitting Teflon pestle. The rotor speed was 300-500 r.p.m. and the pestle was raised and lowered four to five times. The homogenate was centrifuged at $105000 \mathrm{~g}$ for $1 \mathrm{~h}$ and passed through a Sephadex G-25 column $(1 \mathrm{ml}$ column, flow rate $1 \mathrm{ml} / 40 \mathrm{~min})$ at $4{ }^{\circ} \mathrm{C}$ to remove endogenous catecholamines as described by Yamauchi \& Fujisawa (1978). The eluate containing TH activity was stored up to 1 week at $-20^{\circ} \mathrm{C}$ and used as the enzyme preparation for the assay. Enzyme activity was not affected by storage up to 1 week (data not shown).

\section{TH assay}

$\mathrm{TH}$ activity was measured by the method of Shiman et al. (1971). To $150 \mu \mathrm{l}$ of the enzyme fraction, $0.25 \mathrm{ml}$ L-tyrosine $(2 \mathrm{mM})$ in distilled water, potassium phosphate-buffered saline (PBS) buffer $(2 \cdot 0 \mathrm{M}, \mathrm{pH} 6 \cdot 2)$, $0.01 \mathrm{ml}$ catalase $(1 \mathrm{mg} / 3 \mathrm{ml}$ in PBS buffer), $0.05 \mathrm{ml}$ 2-mercaptoethanol $(0 \cdot 28 \mathrm{M})$ in distilled water and $0.05 \mathrm{ml}$ $\mathrm{DMPH}_{4}(6 \mathrm{mM})$ in $0.005 \mathrm{M} \mathrm{HCl}$ (prepared just before use and kept in ice) were added in the same order. The reaction mixture was incubated in a test tube at $30{ }^{\circ} \mathrm{C}$ for
$25 \mathrm{~min}$. Reaction was stopped by adding $0.5 \mathrm{ml} 0.5 \mathrm{M}$ $\mathrm{HCl}$. Freshly prepared nitrite-molybdate $(1 \mathrm{ml})$ reagent was added to the mixture and allowed to stand for at least $5 \mathrm{~min}$. The colour was stable for $30 \mathrm{~min}$ and $0.5 \mathrm{ml} 2 \mathrm{M}$ $\mathrm{NaOH}$ solution was quickly added and mixed. Absorption was immediately determined at $510 \mathrm{~nm}$ in a UV-VIS spectrophotometer (Systronics, ASE Ltd, Ahmedabad, India). To express enzyme activity, tissue protein content in each aliquot was measured by the method of Lowry et al. (1951) using BSA as standard. Enzyme activity was expressed in nmol L-DOPA formed/mg protein per h.

\section{Determination of $\mathrm{K}_{m}$ and maximum velocity $\left(V_{\max }\right)$ for} L-tyrosine (substrate) and $\mathrm{DMPH}_{4}$ (cofactor)

Michaelis-Menten constants $\left(K_{\mathrm{m}}\right)$ for the substrate and cofactor, and maximum velocity $\left(\mathrm{V}_{\max }\right)$ of the enzyme were determined from double reciprocal Lineweaver-Burk (LB) plots (Price \& Stevens 1999). The enzyme preparation was incubated in different concentration ranges of L-tyrosine $(0.1-0.5 \mathrm{mM})$ and $\mathrm{DMPH}_{4}(1-8 \mathrm{mM})$ to measure $\mathrm{TH}$ activity as stated above. The $K_{\mathrm{m}}$ and $\mathrm{V}_{\max }$ were calculated from the intercepts $\left(-1 / K_{\mathrm{m}}\right.$ and $1 / \mathrm{V}_{\max }$ respectively) on the $\mathrm{x}$ and $\mathrm{y}$ axes of the LB plots.

\section{Statistical analysis}

All data are expressed as means \pm S.E.M. and were analysed by two-way (ovariectomy) and one-way ANOVA ( $\mathrm{OE}_{2}$ replacement) followed by Tukey's test $(P<0 \cdot 05)$.

\section{Results}

Effects of ovariectomy on brain TH activity

Ovariectomy produced overall significant effects on $\mathrm{TH}$ activity in different regions of the brain in resting 
(hypothalamus $\mathrm{F}=8.33$, telencephalon $\mathrm{F}=11.46$ and medulla oblongata $\mathrm{F}=6 \cdot 24$ ) and prespawning (hypothalamus $\mathrm{F}=16 \cdot 28$, telencephalon $\mathrm{F}=20 \cdot 35$ and medulla oblongata $\mathrm{F}=8.62$ ) phases (Fig. 2; $P<0 \cdot 001$, two-way ANOVA), when measured under saturating conditions of substrate and cofactor. The analysis also showed a highly significant effect of ovariectomy and duration, and of the interaction between these two factors in all brain regions in the resting and prespawning phases $(P<0 \cdot 001)$. Multiple comparisons by Tukey's test showed that, in the resting phase, TH activity did not vary significantly in week 1 but decreased significantly from week 2 onwards in a duration-dependent manner $(P<0 \cdot 05$; Fig. $2 \mathrm{a}, \mathrm{c}$ and e). In the prespawning phase, the ovariectomy-induced inhibition of enzyme activity was significantly different in weeks 3, 4 and 5 ( $P<0 \cdot 05$, Fig. $2 b, d$ and f).

\section{Effects of $\mathrm{OE}_{2}$ replacement on brain $\mathrm{TH}$ activity}

Administration of $\mathrm{OE}_{2}$ in 3-week ovariectomised fish produced an overall significant effect on brain $\mathrm{TH}$ activity (Fig. 3; $P<0 \cdot 001$, one-way ANOVA; resting phase: hypothalamus $\mathrm{F}=146 \cdot 37$, telencephalon $\mathrm{F}=109 \cdot 71$, medulla oblongata $\mathrm{F}=79 \cdot 23$; prespawning phase: hypothalamus $\mathrm{F}=168 \cdot 76$, telencephalon $\mathrm{F}=137 \cdot 65$ and medulla oblongata $F=79 \cdot 32$ ), when measured under saturating conditions of substrate and cofactor. In both phases, $\mathrm{OE}_{2}$ produced dosage-dependent biphasic effects on enzyme activity. The low dosages $(0.05$ and $0.5 \mu \mathrm{g} / \mathrm{g}$ BW) not only restored TH activity, but also elevated it significantly $(P<0 \cdot 05)$. The high dosages $(1.0$ and $2.0 \mu \mathrm{g} / \mathrm{g}$ $\mathrm{BW})$ decreased the enzyme activity significantly $(P<0 \cdot 05)$. The magnitude of the inhibition was higher in the resting phase (December) than in the prespawning phase (May). In the resting phase, the enzyme inhibition for the $2.0 \mu \mathrm{g} / \mathrm{g}$ dosage was $71 \%$ (hypothalamus), $58 \%$ (telencephalon) and 69\% (medulla oblongata) and in the prespawning phase it was $31 \%, 30 \%$ and $31 \%$ respectively.

\section{Effects of ovariectomy on enzyme kinetics}

Figure 4 shows that ovariectomy affected both apparent $K_{\mathrm{m}}$ and $\mathrm{V}_{\max }$ of $\mathrm{TH}$ and the inhibition appeared to be of the mixed or uncompetitive type. Ovariectomy produced overall significant effects on the apparent $K_{\mathrm{m}}$ and $\mathrm{V}_{\max }$ of the enzyme (Figs 5 and 6; $P<0 \cdot 001$, one-way ANOVA). The apparent $K_{\mathrm{m}}$ values for the substrate (L-tyrosine) and cofactor $\left(\mathrm{DMPH}_{4}\right)$ showed an increasing trend over the period of ovariectomy in both resting and prespawning phases. In the resting phase, the apparent $K_{\mathrm{m}}$ values for the substrate (Fig. 5) were significantly higher in weeks 4 and 5 in the hypothalamus, weeks 3,4 and 5 in the telencephalon and weeks $2,3,4$ and 5 in the medulla oblongata $(P<0 \cdot 05$; Tukey's test $)$ in comparison to the sham-ovariectomised group. In the prespawning phase, the values were significantly high in weeks $2,3,4$ and 5 in all the brain regions. The apparent $K_{\mathrm{m}}$ values for the cofactor (Fig. 6) were significantly higher in weeks 3, 4 and 5 in the hypothalamus, weeks $2,3,4$, and 5 in the telencephalon and at all times in the medulla oblongata in the resting phase $(P<0 \cdot 05)$. In the prespawning phase, the values were significantly higher in weeks 3,4 and 5 in all the brain regions.

$\mathrm{V}_{\max }$ of the enzyme for the substrate and cofactor showed overall significant changes in both seasons following ovariectomy (Figs 5 and $6 ; P<0 \cdot 001$, one-way ANOVA) showing a decreasing tendency over the duration of ovariectomy. For the substrate, the values decreased significantly in all regions except in the hypothalamus in week 1 in the resting phase and at all times in the prespawning phase when compared with the shamovariectomised group $(P<0 \cdot 05)$. In the resting phase, $\mathrm{V}_{\max }$ for the cofactor was reduced significantly at all times except in week 1 in the telencephalon and hypothalamus. In the prespawning phase, $\mathrm{V}_{\max }$ values for the cofactor were decreased significantly from week 2 onwards in medulla oblongata and week 3 onwards in the telencephalon and hypothalamus $(P<0 \cdot 05)$.

\section{Effects of $\mathrm{OE}_{2}$ replacement on enzyme kinetics}

$\mathrm{OE}_{2}$ replacement produced significant overall effects in both apparent $K_{\mathrm{m}}$ and $\mathrm{V}_{\max }$ values of the enzyme (Figs 7 and $8 ; P<0 \cdot 001$; one-way ANOVA). The $K_{\mathrm{m}}$ values showed dosage-dependent biphasic effects. The low dosages $(0.05$ and $0.5 \mu \mathrm{g} / \mathrm{g})$ decreased the $K_{\mathrm{m}}$ values significantly in all the brain regions in both seasons $(P<0 \cdot 05)$, compared with the ovariectomised, vehicletreated control groups. The high dosages $(1 \cdot 0$ and $2 \cdot 0 \mu \mathrm{g} / \mathrm{g}$ $\mathrm{BW}$ ) increased the values significantly in all the brain regions in both seasons $(P<0 \cdot 05)$.

$\mathrm{OE}_{2}$ replacement elicited dose-related effects on the $\mathrm{V}_{\max }$. The low dosages $(0.05$ and $0.5 \mu \mathrm{g} / \mathrm{g})$ elevated it maximally. In the high dosage $(1 \cdot 0$ and $2 \cdot 0 \mu \mathrm{g} / \mathrm{g})$ groups, the values were significantly higher than the ovariectomised, vehicle-treated groups (control) in all the groups except the values of hypothalamus and telencephalon for the substrate (Fig. 7) in the resting phase and that of the medulla oblongata in the prespawning phase which were significantly lower than the control value.

\section{Discussion}

In the catfish Heteropneustes fossilis, ovariectomy and $\mathrm{OE}_{2}$ replacement procedures have been used previously to investigate oestrogen-monoamine interaction in the control of $\mathrm{LH}$ secretion. These studies indicate that $\mathrm{OE}_{2}$ interacts with the hypothalamic CA system at different enzyme-catalysed metabolic steps (D $\beta \mathrm{H}$, PNMT, COMT and monoamine oxidase (MAO)) to alter CA activity 

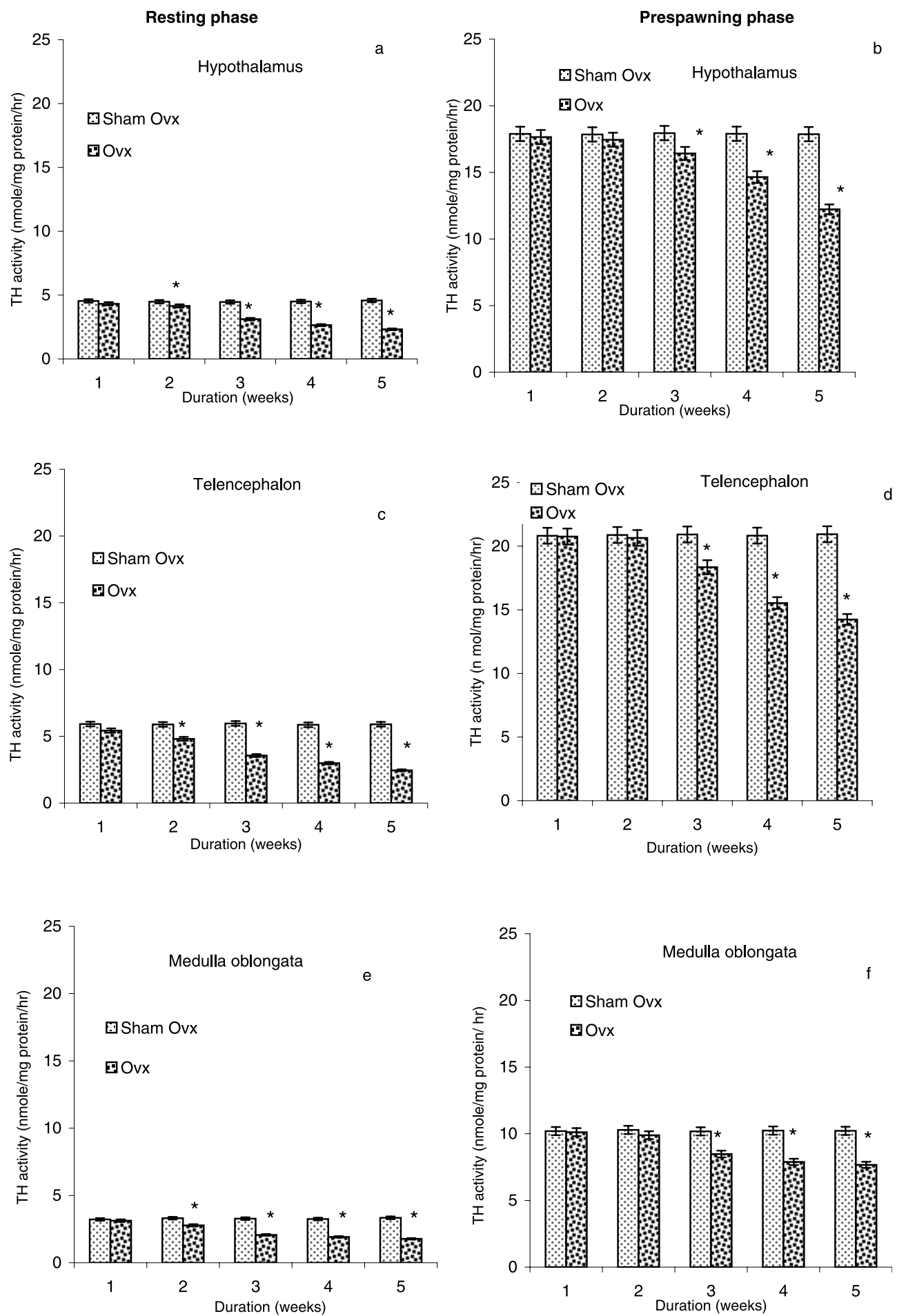

Figure 2 Effects of ovariectomy $(\mathrm{Ovx})$ /sham-ovariectomy (Sham Ovx) on TH activity in hypothalamus (a and b), telencephalon (c and d) and medulla oblongata (e and f) in Heteropneustes fossilis in resting and prespawning phases. Values are means \pm S.E.M.; $n=5$. Asterisks show significant differences from sham-ovariectomised groups (Tukey's test, $P<0 \cdot 05$ ). 
25

Resting phase
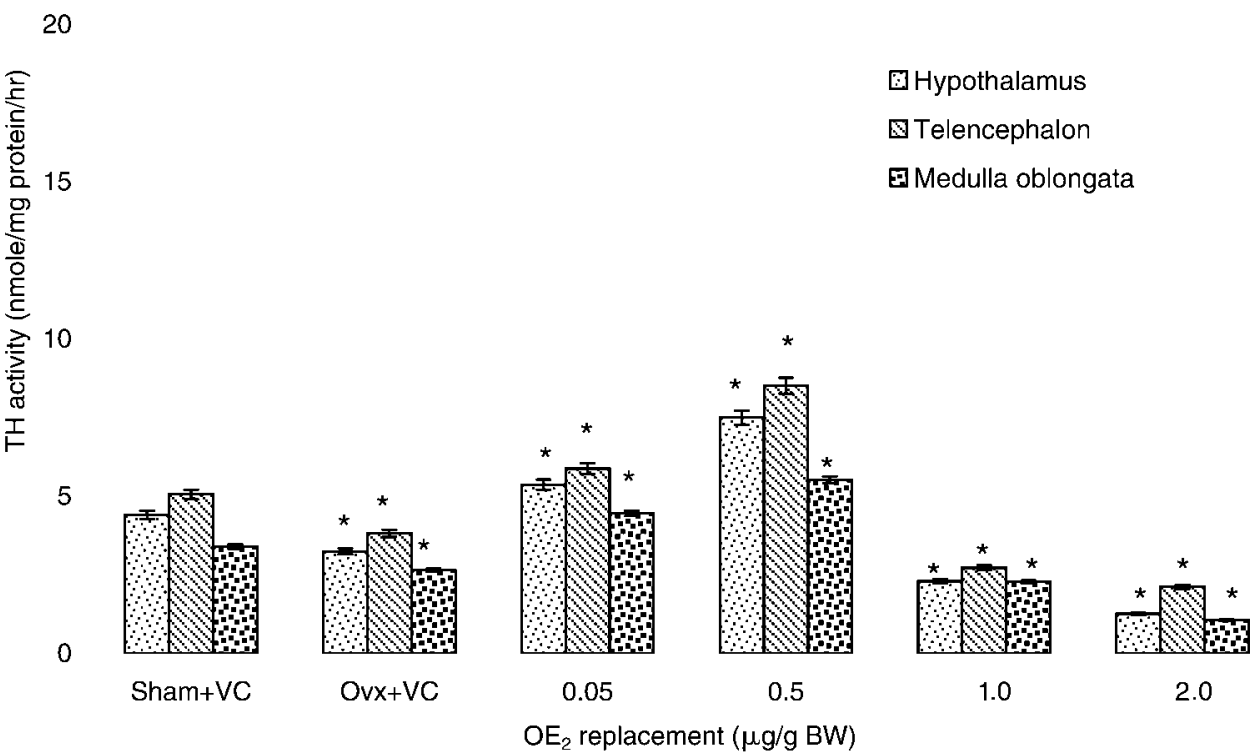

Prespawning phase
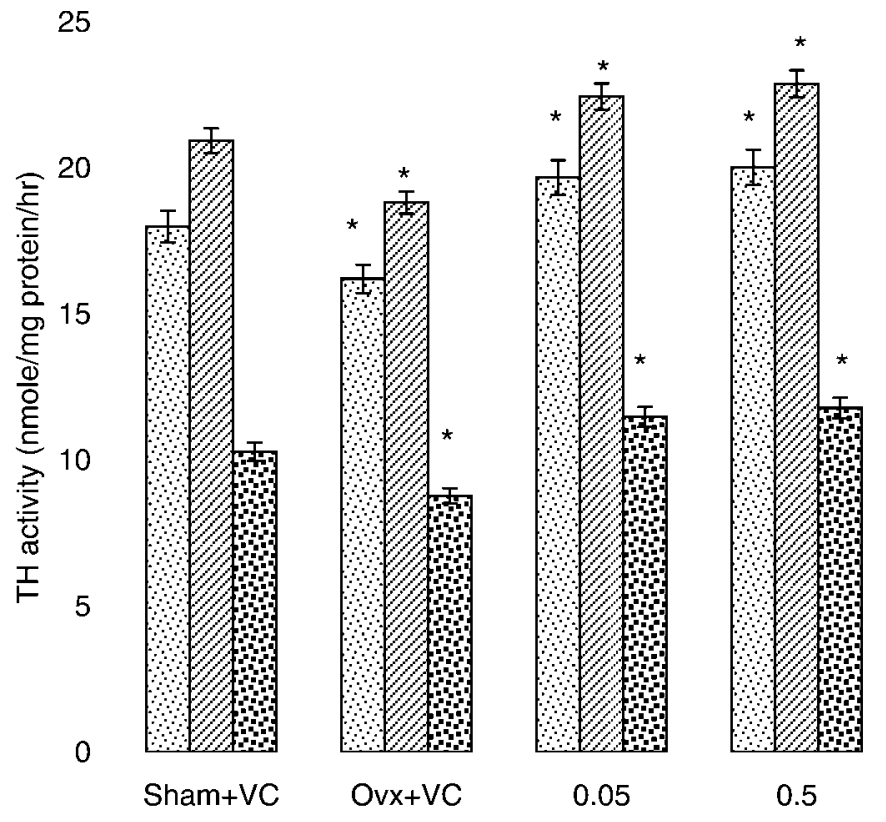

GHypothalamus

๑Telencephalon

a Medulla oblongata

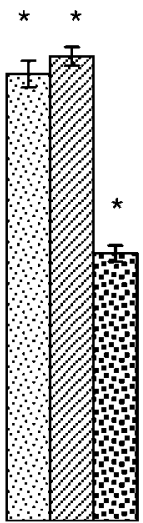

1.0

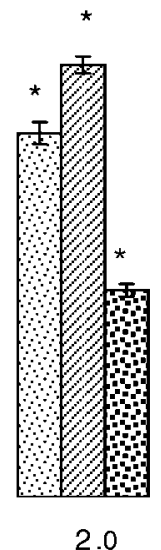

$\mathrm{OE}_{2}$ replacement $(\mu \mathrm{g} / \mathrm{g} \mathrm{BW})$

Figure 3 Effects of $\mathrm{OE}_{2}$ replacement on $\mathrm{TH}$ activity in hypothalamus, telencephalon and medulla oblongata in 3-week ovariectomised (Ovx) Heteropneustes fossilis in resting and prespawning phases. Values are means \pm S.E.M.; $n=5$. Asterisks show significant differences between sham + vehicle control (VC) and Ovx $+V C$, and $\mathrm{OE}_{2}$-treated groups and $\mathrm{Ovx}+\mathrm{VC}$ groups (Tukey's test, $P<0 \cdot 05$ ). 

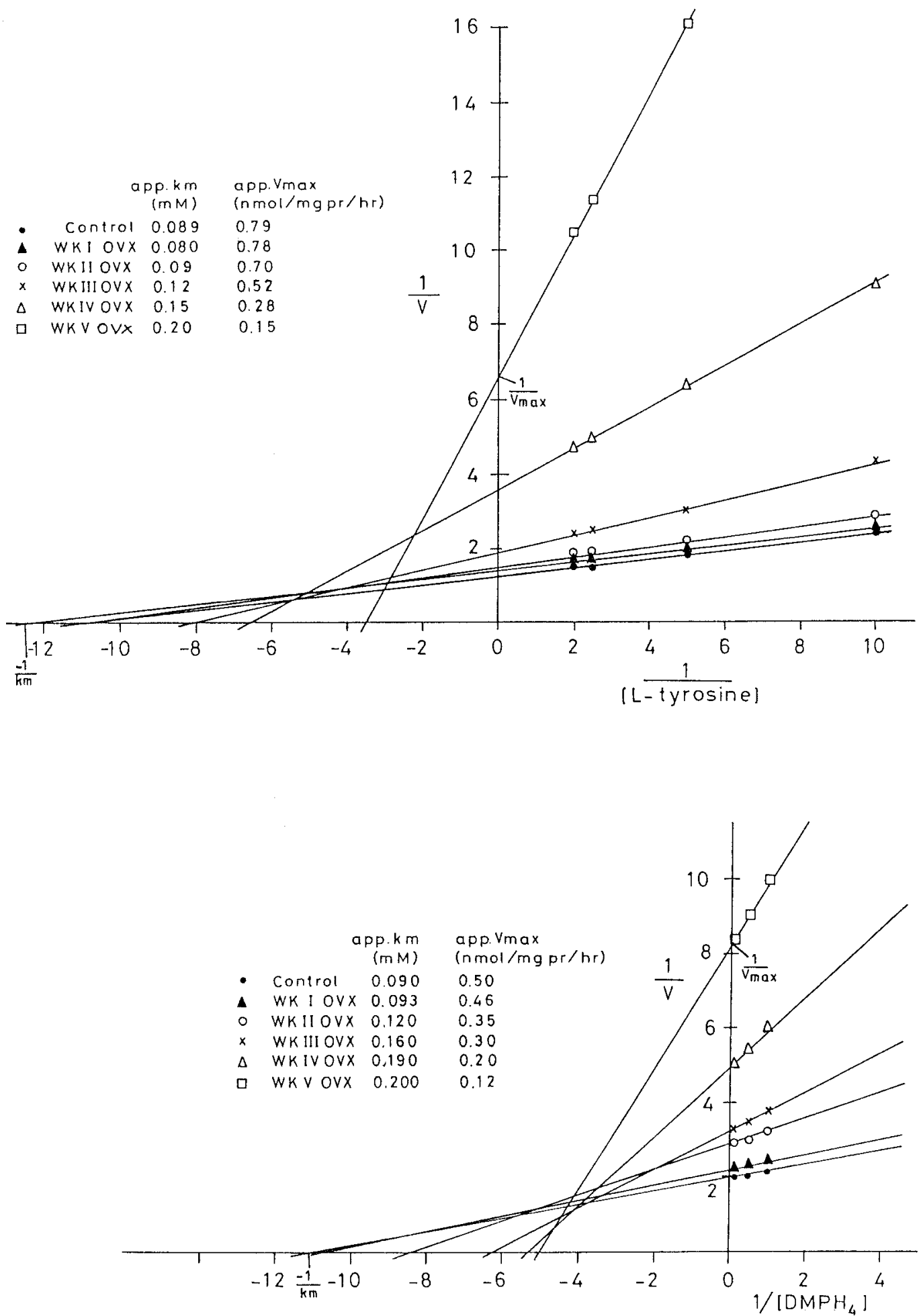

Figure $4 \mathrm{LB}$ plots of TH activity for substrate (L-tyrosine) and cofactor $\left(\mathrm{DMPH}_{4}\right)$ in the hypothalamus (resting phase) showing apparent (app.) $K_{\mathrm{m}}(\mathrm{km}) / \mathrm{V}_{\max }$ of ovariectomised $(\mathrm{OVX})$ and sham-ovariectomised (control) groups. The control data are pooled from sham-ovariectomised groups of all weeks (WK). $\frac{1}{v}$ denotes reciprocal of velocity of enzyme (measured activity) reaction. 

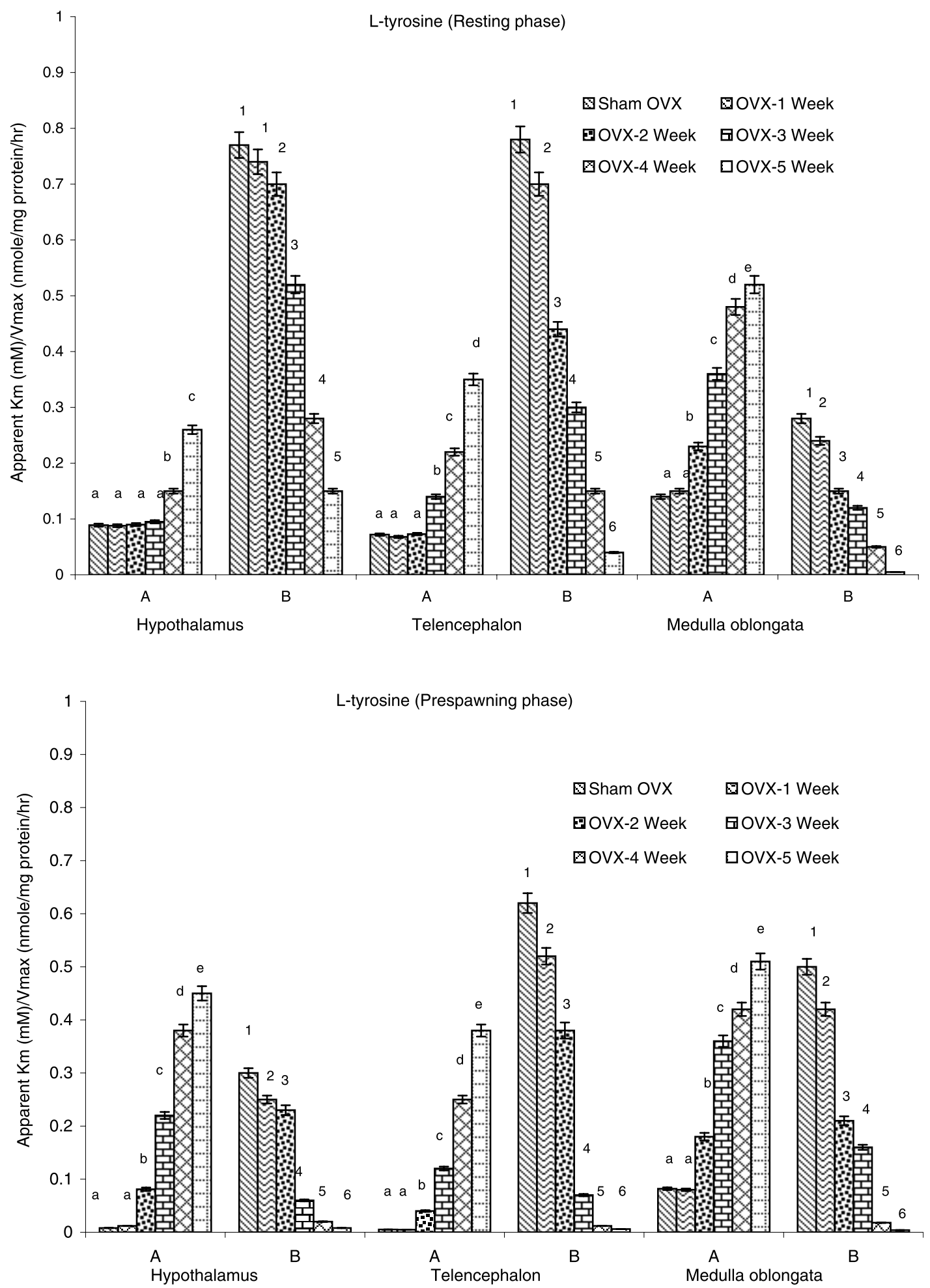

Figure 5 Effects of ovariectomy $(\mathrm{OVX})$ /sham-ovariectomy (Sham OVX, pooled data of weeks 1, 2, 3, 4 and 5) on kinetics of brain TH activity for substrate (L-tyrosine) $\left(K_{m}(A)\right.$ and $\left.V_{\max }(B)\right)$ in Heteropneustes fossilis in resting and prespawning phases. Values are means \pm S.E.M.; $n=5$. Groups bearing the same numbers or letters are not significantly different from sham-ovariectomised groups and those bearing different numbers or letters are significantly different (Tukey's test, $P<0 \cdot 05)$. 

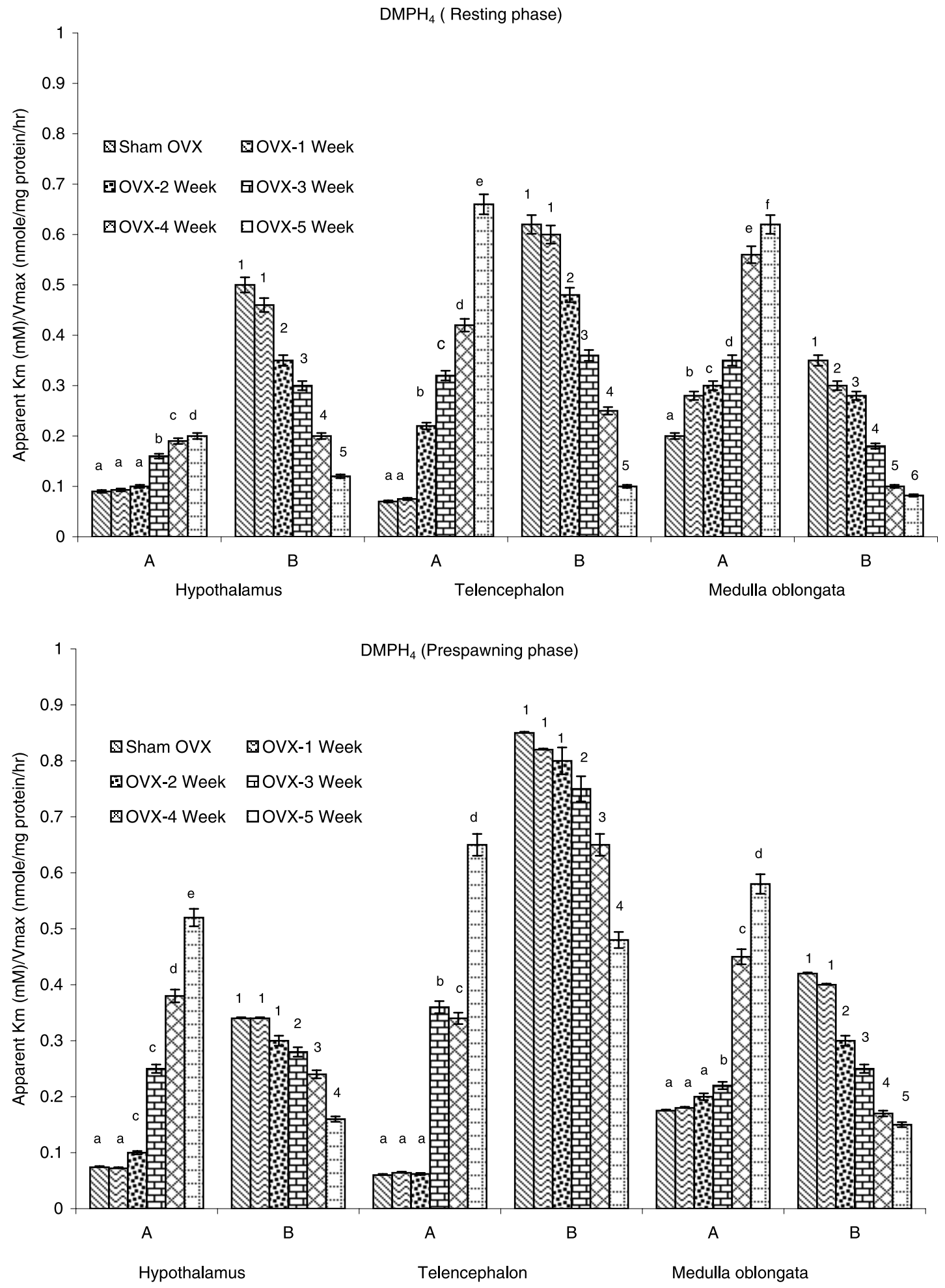

Figure 6 Effects of ovariectomy $(\mathrm{OVX})$ /sham-ovariectomy (Sham OVX, pooled data of weeks 1, 2, 3, 4 and 5) on kinetics of brain $\mathrm{TH}$ activity for cofactor $\left(\mathrm{DMPH}_{4}\right)\left(K_{\mathrm{m}}(\mathrm{A})\right.$ and $\left.\mathrm{V}_{\max }(\mathrm{B})\right)$ in Heteropneustes fossilis in resting and prespawning phases. Values are means \pm S.E.M.; $n=5$. Groups bearing the same numbers or letters are not significantly different from sham-ovariectomised groups and those bearing different numbers or letters are significantly different (Tukey's test, $P<0 \cdot 05)$. 
L-tyrosine (Resting phase)
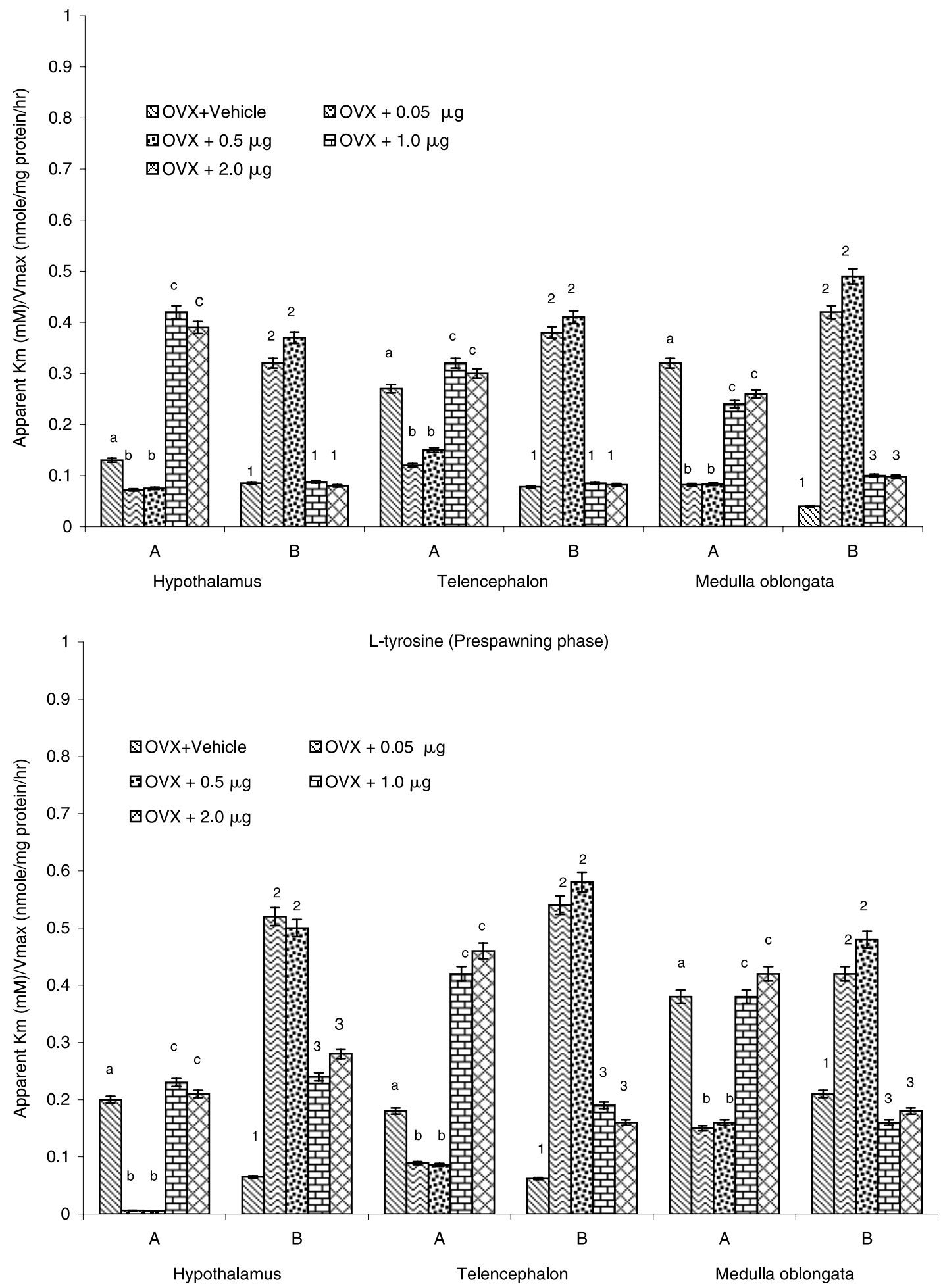

Figure 7 Effects of $\mathrm{OE}_{2}$ replacement on kinetics of brain $\mathrm{TH}$ activity for substrate (L-tyrosine) $\left(K_{\mathrm{m}}(\mathrm{A})\right.$ and $\left.\mathrm{V}_{\max }(\mathrm{B})\right)$ in 3 -week ovariectomised (OVX) Heteropneustes fossilis in resting and prespawning phases. Values are means \pm S.E.M.; $n=5$. Groups bearing the same numbers or letters are not significantly different and those bearing different numbers or letters are significantly different (Tukey's test, $P<0 \cdot 05)$. 

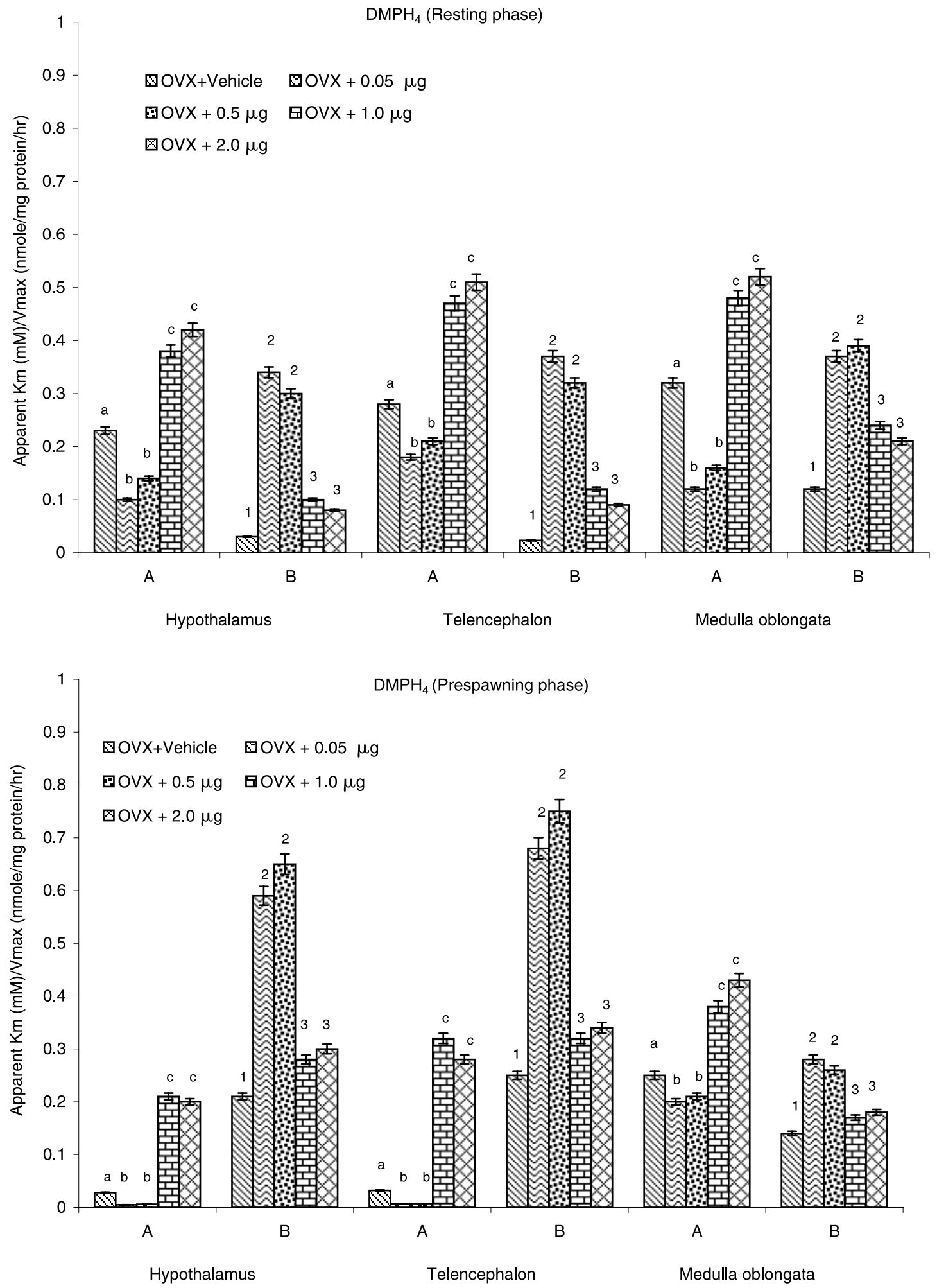

Figure 8 Effects of $\mathrm{OE}_{2}$ replacement on kinetics of TH activity for cofactor $\left(\mathrm{DMPH}_{4}\right)\left(K_{\mathrm{m}}(\mathrm{A})\right.$ and $\left.\mathrm{V}_{\max }(\mathrm{B})\right)$ in 3 -week ovariectomized (OVX) Heteropneustes fossilis in resting and prespawning phases. Values are means \pm S.E.M.; $n=5$. Groups bearing the same numbers or letters are not significantly different and those bearing different numbers or letters are significantly different (Tukey's test, $P<0 \cdot 05)$. 
which, in turn, regulates LH secretion (Senthilkumaran \& Joy 1994, 1995, Joy \& Senthilkumaran 1998). The results of the present study conducted in an identical manner in the corresponding seasons have demonstrated that tyrosine hydroxylation is yet another step in CA metabolism influenced by $\mathrm{OE}_{2}$. In the recrudescent phase (prespawning phase), ovariectomy, which produced a duration-dependent decrease in plasma $\mathrm{OE}_{2}$ level and consequent $\mathrm{OE}_{2}$ feedback-induced increase in plasma $\mathrm{LH}$ (Senthilkumaran \& Joy 1994, 1995), caused an inhibitory effect on TH activity. The response was greater in the hypothalamus and telencephalon than in the medulla oblongata, suggesting a strong involvement of the forebrain $\mathrm{CA}$ system in the $\mathrm{OE}_{2}$ feedback regulation of $\mathrm{LH}$. Comparable studies are lacking in other teleosts but in rainbow trout a significant decrease in mRNA level was reported after ovariectomy in nucleus preopticusanteroventralis (Vetillard et al. 1999). In contrast, studies in the rat showed that gonadectomy led to an increase in $\mathrm{TH}$ activity in the hypothalamus of females (Beattie et al. 1972) and the median eminence of males (Kizer et al. 1974, Babu \& Vijayan 1984). Nakahara et al. (1976), however, showed that the response to castration varied with the hypothalamic nuclei studied.

The ovariectomy-induced inhibition of $\mathrm{TH}$ activity was reversed by the administration of low dosages $(0.05$ and $0.5 \mu \mathrm{g} / \mathrm{g} \mathrm{BW}$ ) of $\mathrm{OE}_{2}$. In rainbow trout, $\mathrm{OE}_{2}$ partially reversed the effect of ovariectomy on TH mRNA level (Vetillard et al. 1999). In the rat, a combination of $\mathrm{OE}_{2}$ and progesterone increased the in situ molar activity of $\mathrm{TH}$ in the rat median eminence (Anguila-Mansilla et al. 1991). $\mathrm{OE}_{2}$ elevated hypothalamic TH activity in the ovariectomised rat and progesterone decreased it in ovariectomised and ovariectomised+oestrogen-treated rats (Beattie et al. 1972, Babu \& Vijayan 1984). In the ovariectomised rat, low-dose $\mathrm{OE}_{2}$ implants for 3 days reduced $\mathrm{TH}$ mRNA levels but large-dose $\mathrm{OE}_{2}$ implants for 20 days depressed the mRNA levels further, removal of the implants resulted in the TH mRNA levels returning to a level higher than ovariectomised control values (Rasmussen et al. 1992). In the catfish, the effect of $\mathrm{OE}_{2}$ was biphasic depending on the dosage. The low dosages elevated enzyme activity significantly above the control values, but the high dosages $(1.0$ and $2.0 \mu \mathrm{g} / \mathrm{g} \mathrm{BW})$ inhibited it. Similar biphasic effects of $\mathrm{OE}_{2}$ have been demonstrated on hypothalamic $\mathrm{D} \beta \mathrm{H}$, PNMT, MAO and COMT activities in the catfish after ovariectomy (Senthilkumaran \& Joy 1994, 1995, Joy \& Senthilkumaran 1998). Such graded effects from stimulatory to inhibitory, as the dosage is increased, represent a non-monotonic or inverted-U response which is characteristic of the actions of oestrogen in other biological systems (Vom Saal et al. 1997).

The functional significance of the effects of $\mathrm{OE}_{2}$ on brain $\mathrm{TH}$ activity during the gonadal recrudescent (prespawning) phase can be related to the CA control of LH secretion (DA inhibits and NA/adrenaline stimulates LH secretion) in the catfish (Senthilkumaran \& Joy 1995, Goos et al. 1999, Joy 1999). During ovariectomy, plasma LH levels were elevated with the peak at week 4 by depressing DA content and turnover, and elevating NA/adrenaline content and turnover. Further $\mathrm{OE}_{2}$ treatment in 3-week ovariectomised catfish reversed the patterns in LH secretion and CA activity in a dose-dependent manner. The differential changes in CA activity could also be correlated with changes in $\mathrm{D} \beta \mathrm{H}$ and PNMT activity (Senthilkumaran \& Joy 1995). Since we sampled the tissues only at 7 days after ovariectomy, a stimulatory response prior to it, if there was one, was missed in this study. The insignificant change observed at weeks 1 and 2 may be the course of changes from a stimulatory to an inhibitory one during ovariectomy. This needs to be verified in further studies. The elevated TH activity in low $\mathrm{OE}_{2}$ dosage groups suggests increased CA synthesis/ affinity of the enzyme for the substrate and cofactor. The inhibitory effect due to long-term ovariectomy $(4,5$ and 6 weeks) and high dosages of $\mathrm{OE}_{2}(1 \cdot 0$ and $2 \cdot 0 \mu \mathrm{g} / \mathrm{g} \mathrm{BW})$ suggests decreased synthesis/affinity of the enzymes for both substrate and cofactor. The $\mathrm{OE}_{2}$ effect on $\mathrm{TH}$ activity may be produced directly (see below) or indirectly by altering CA activity which may exert end-product feedback control of the enzyme.

The significance of changes in $\mathrm{TH}$ activity due to ovariectomy and $\mathrm{OE}_{2}$ replacement in the gonadal quiescent (resting) phase is not clear at present. In fact, the inhibition to $\mathrm{OE}_{2}$ replacement was stronger in the resting phase. Perhaps the changes may indicate CA (DA) involvement in maintaining the pituitary-gonad axis in a quiescent state. During this phase, DA is the principal CA, and NA, adrenaline and their synthesising enzymes are absent or show low activity (Senthilkumaran \& Joy 1995). In our earlier studies, we could not show any effect of ovariectomy or $\mathrm{OE}_{2}$ replacement on hypothalamic CAs or on $\mathrm{D} \beta \mathrm{H}, \mathrm{PNMT}, \mathrm{COMT}$ or $\mathrm{MAO}$ in the resting phase (Senthilkumaran \& Joy 1994, 1995, Joy \& Senthilkumaran 1998). The TH response may indicate that it is a more highly sensitive index of CA metabolism than the other parameters. Apart from $\mathrm{LH}$ regulation, DA is also involved in the regulation of $\mathrm{GH}$, prolactin and melanocytestimulating hormone secretion in teleosts (Peter \& Yu 1997, Olivereau \& Olivereau 1999a,b) and the actions of $\mathrm{OE}_{2}$ on $\mathrm{TH}$ activity can modify these DA-dependent functions, apart from other neural functions.

The kinetic data show that both ovariectomy and $\mathrm{OE}_{2}$ replacement influenced the kinetic properties of the enzyme and the observed in vivo activity changes in the enzyme can be correlated. Ovariectomy resulted in an increase in the apparent $K_{\mathrm{m}}$ values for both substrate and cofactor with a consequent decrease in $\mathrm{V}_{\max }$ over its duration. These results indicate that ovariectomy decreased the affinity of the enzyme for the substrate and cofactor. Since both apparent $K_{\mathrm{m}}$ and $\mathrm{V}_{\max }$ were altered 
by $\mathrm{OE}_{2}$, the interaction may be uncompetitive or mixed (Price \& Stevens 1999). Ovariectomy in the rat increased hypothalamic $\mathrm{TH}$ activity with a concurrent decrease in apparent $K_{\mathrm{m}}$ value for $\mathrm{DMPH}_{4}$ (cofactor; Beattie et al. 1972). Progesterone did not alter the $K_{\mathrm{m}}$ and $\mathrm{V}_{\max }$ of hypothalamic $\mathrm{TH}$ for tyrosine but that for the cofactor was altered $\left(K_{\mathrm{m}}\right.$ increased, $\mathrm{V}_{\max }$ decreased; Beattie \& Soyka 1973). However, Morgenroth et al. (1974) have reported changes in the $K_{\mathrm{m}}$ and $\mathrm{V}_{\max }$ for substrate as well. In the catfish, we have reported changes in apparent $K_{\mathrm{m}}$ values for both substrate and cofactor across the seasons, sexes and brain regions (Chaube \& Joy 2002a,b). It is possible that the concentration of the substrate may be a critical factor for $\mathrm{TH}$ activity in fish.

$\mathrm{OE}_{2}$ replacement produced biphasic effects on the kinetic parameters. The low steroid dosages decreased the apparent $K_{\mathrm{m}}$ values and increased the $\mathrm{V}_{\max }$ concurrently, which may explain the stimulatory effect on in vivo $\mathrm{TH}$ activity. On the other hand, the high dosages of the steroid produced effects opposite to that of the low dosages, resulting in $\mathrm{TH}$ inhibition in vivo. In rainbow trout, $\mathrm{OE}_{2}$ did not affect apparent $K_{\mathrm{m}}$ and $\mathrm{V}_{\max }$ of $\mathrm{TH}$ in the hypothalamus and telencephalon, but 2-hydroxyoestradiol decreased the affinity for cofactor (elevated $K_{\mathrm{m}}$ and decreased $V_{\text {max }}$ ) (Saligaut et al. 1993) as has been reported in mammals (Foreman \& Porter 1980).

It is known that the regulation of $\mathrm{TH}$ activity involves two mechanisms: acute regulation in which the rapid increase in activity upon nerve stimulation is attributed to a decrease in end-product inhibition and activation by phosphorylation, and long-term regulation in which the delayed response is related to changes in protein amount (Joh et al. 1978, Zigmond et al. 1989). $\mathrm{OE}_{2}$ has been demonstrated to modify $\mathrm{TH}$ synthesis by regulating transcriptional activity (Blum et al. 1987, Zigmond et al. 1989, Selmanoff et al. 1991, Rasmussen et al. 1992, Vetillard et al. 1999). Further, it has been demonstrated that $\mathrm{OE}_{2}$ can act at the membrane level (Thomas 1999, Russell et al. 2000, Cambiasso \& Carrer 2001) to modulate signal transduction pathways that alter the phosphorylation status of the enzyme (Arbogast \& Voogt 1991, Du \& Iacovitti 1997, Arbogast \& Hyde 2000). Therefore, it is likely that the alteration in the $\mathrm{TH}$ activity due to ovariectomy and $\mathrm{OE}_{2}$ replacement may involve both genomic and non-genomic actions.

In conclusion, the present results clearly show that $\mathrm{OE}_{2}$ exerts biphasic effects on brain $\mathrm{TH}$ activity and is an important mechanism of the steroid regulation of CA activity in the catfish.

\section{Acknowledgements}

The work was supported by a UGC research grant to K P J. R C is grateful to the CSIR, New Delhi for the award of a senior research fellowship.

\section{References}

Ames MM, Lerner P \& Lovenberg W 1978 Tyrosine hydroxylase: activation by protein phosphorylation and end product inhibition. Journal of Biological Chemistry 253 27-31.

Anguila-Mansilla N, Jorquera BA, Kedzierski W \& Porter JC 1991 Effect of cerebroventricular anterior pituitary grafts on in situ expression of tyrosine hydroxylase in dopaminergic neurons of the aged animal. Endocrinology 128 1303-1309.

Arbogast LA \& Voogt JL 1991 Mechanisms of tyrosine hydroxylase regulation during pregnancy: evidence for protein dephosphorylation during the prolactin surges. Endocrinology 129 2575-2582.

Arbogast LA \& Hyde JF 2000 Estradiol attenuates the forskolin-induced increase in hypothalamic tyrosine hydroxylase activity. Neuroendocrinology 4 219-227.

Babu GN \& Vijayan E 1984 Hypothalamic tyrosine hydroxylase activity and plasma gonadotropin and prolactin levels in ovariectomised-steroid treated rats. Brain Research Bulletin $\mathbf{5}$ $555-558$

Beattie CW \& Soyka LF 1973 Influence of progestational steroids on hypothalamic tyrosine hydroxylase in vitro. Endocrinology 93 1453-1455.

Beattie CW, Rodgers CH \& Soyka LF 1972 Influence of ovariectomy and ovarian steroids on hypothalamic tyrosine hydroxylase activity in the rat. Endocrinology 92 276-279.

Blum M, McEwen BS \& Roberts JL 1987 Transcriptional analysis of tyrosine hydroxylase gene expression in the tuberoinfundibular dopaminergic neurons of the rat arcuate nucleus after estrogen treatment. Journal of Biological Chemistry 262 817-821.

Cambiasso MJ \& Carrer HF 2001 Nongenomic mechanism mediates estradiol stimulation of axon growth in male rat hypothalamic neurons in vitro. Journal of Neuroscience Research $\mathbf{6 6}$ 475-481.

Chaube R \& Joy KP 2002a Effects of altered photoperiod and temperature, serotonin- affecting drugs, and melatonin on brain tyrosine hydroxylase activity in female catfish, Heteropneustes fossilis: a study correlating ovarian activity changes. Journal of Experimental Zoology 293 585-593.

Chaube R \& Joy KP $2002 b$ Brain tyrosine hydroxylase in the catfish Heteropneustes fossilis: annual and circadian variations and sex and regional differences in enzyme activity and some kinetic properties. General and Comparative Endocrinology (In Press) (www.interscience.wiley.com).

Du X \& Iacovitti L 1997 Multiple pathways direct the inhibition of tyrosine hydroxylase gene expression in cultured brain neurons. Molecular Brain Research 50 1-8.

Ekstrom P, Holmqvist I \& Panula P 1995 Histamine-immunoreactive neurons in the brain of the teleost Gasterosteus aculeatus (L). Correlation with hypothalamic tyrosine hydroxylase- and serotonin-immunoreactive neurons. Journal of Chemical Neuroanatomy $875-85$.

Foreman MM \& Porter JC 1980 Effects of catecholestrogens and catecholamines on hypothalamic and corpus striatal tyrosine hydroxylase activity. Journal of Neurochemistry 34 1175-1183.

Gonzales HA, Kedzierski W, Anguila-Mansilla N \& Porter JC 1989 Hormonal control of tyrosine hydroxylase in the median eminence: demonstration of a central role for the pituitary gland. Endocrinology 124 2122-2127.

Goos HJTh, Senthilkumaran, B \& Joy KP 1999 Neuroendocrine integrative mechanisms in the control of gonadotropin secretion in teleosts. In Comparative Endocrinlogy and Reproduction, pp 113-136. Eds KP Joy, A Krishna \& C Haldar. New Delhi, Berlin: Narosa, Springer-Verlag.

Guerrero HV, Caceres G, Paia CL \& Marcano D 1990 Hypothalamic and telencephalic catecholamine content in the brain of the teleost fish, Pygocentrus notatus, during the annual reproductive cycle. General and Comparative Endocrinology 80 257-263. 
Hornby PJ \& Piekut DT 1990 Distribution of catecholaminesynthesizing enzymes in goldfish brains: presumptive dopamine and norepinephrine neuronal organization. Brain Behavior and Evolution 35 49-64.

Hernandez-Rauda R, Razas G, Rey P, Otero J \& Aldegunde M 1999 Changes in the pituitary metabolism of monoamines (dopamine, norepinephrine and serotonin) in female and male rainbow trout (Oncorhynchus mykiss) during gonadal recrudescence. Physiological and Biochemical Zoology 72 352-359.

Joh TH, Dong HP \& Reis JD 1978 Direct phosphorylation of brain tyrosine hydroxylase by cyclic AMP-dependent protein kinase: mechanism of enzyme activation. PNAS 75 4744-4748.

Joy KP 1999 Role of central monoamines in regulation of gonadotropin-II secretion. In Neural Regulation in the Vertebrate Endocrine System, pp 111-126. Eds PD Prasada Rao \& RE Peter. New York: Kluwer Academic, Plenum Publishers.

Joy KP \& Senthilkumaran B 1998 Annual and diurnal variations in, and effects of altered photoperiod and temperature, ovariectomy and estradiol-17 $\beta$ replacement on catechol-O-methyl transferase level in brain regions of the catfish Heteropneustes fossilis. Comparative Biochemistry and Physiology 119 37-44.

Kizer JS, Palkovits M, Zivin J, Brownstein M, Saavedra JM \& Kopin IJ 1974 The effect of various endocrinological manipulations on tyrosine hydroxylase and dopamine $\beta$-hydroxylase activities in individual hypothalamic nuclei of the adult male rat. Endocrinology 85 799-812.

Linard B, Bennani S \& Saligaut C 1996a Tyrosine hydroxylase activity and dopamine turnover of rainbow trout (Oncorhynchus mykiss) brain: the special status of the hypothalamus. Fish Physiology and Biochemistry 15 41-48.

Linard B, Anglade I, Corio M, Navas JM, Pakdel F, Saligaut C \& Kah O $1996 b$ Estrogen receptors are expressed in a subset of tyrosine hydroxylase-positive neurons of the anterior preoptic region in the rainbow trout. Neuroendocrinology 63 156-165.

Linard B, Pakdel F, Marmignon MH \& Saligaut C 1998 Cloning of a cDNA coding for active tyrosine hydroxylase in the rainbow trout (Oncorhynchus mykiss): comparison with other hydroxylases and enzymatic expression. Journal of Neurochemistry 71 920-928.

Lowry OH, Rosenbrough NJ, Farr AL \& Randall RJ 1951 Protein measurement with the Folin-phenol reagent. Journal of Biological Chemistry 193 265-275.

Morgenroth VH III, Boadle-Biber M \& Roth RH 1974 Tyrosine hydroxylase: activation by nerve stimulation. PNAS 71 4283-4287.

Nagatsu T, Levitt M \& Udenfriend S 1964 Tyrosine hydroxylase: the initial step in norepinephrine biosynthesis. Journal of Biological Chemistry 239 2910-2917.

Nakahara T, Uchimura H, Hirano M, Saito M \& Ito M 1976 Effects of gonadectomy and thyroidectomy on the tyrosine hydroxylase activity in individual hypothalamic nuclei and lower brain stem catecholaminergic cell groups of the rat. Brain Research 117 351-356.

Olivereau M \& Olivereau JM 1999a Prolactin, ACTH and growth hormone-secreting cells in the teleost pituitary gland: environmental and hypothalamic control. In Comparative Endocrinology and Reproduction, pp 69-92. Eds KP Joy, A Krishna \& C Haldar. New Delhi, Berlin: Narosa, Springer-Verlag.

Olivereau JM \& Olivereau M $1999 b$ The intermediate lobe of teleost fish: POMC-MSH and somatolactin functions, environmental control and enigma. In Comparative Endocrinology and Reproduction, pp 93-112. Eds KP Joy, A Krishna \& C Haldar. New Delhi, Berlin: Narosa, Springer-Verlag.

Peter RE \& Yu KL 1997 Neuroendocrine control of ovulation in fishes: basic and applied aspects. Review of Fish Biology and Fisheries 7 173-197.

Price NC \& Stevens L 1999 Fundamentals of Enzymology: The Cell and Molecular Biology of Catalytic Proteins, edn 3, Chapter 4, pp 118-153. New York: Oxford University Press.
Rasmussen DR, Jakubowski M, Allen DL \& Roberts JL 1992 Positive correlation between proopiomelanocortin and tyrosine hydroxylase mRNA levels in the mediobasohypothalamus of ovariectomized rats: response of estradiol replacement and withdrawal.

Neuroendocrinology 56 285-294.

Russell KS, Haynes MP, Sinha D, Clerisme E \& Bender JR 2000 Human vascular endothelial cells contain membrane binding sites for estradiol, which mediate rapid intracellular signaling. PNAS $\mathbf{9 7}$ 5930-5935

Saligaut C, Bennani S \& Bailhache T 1993 Catecholamine synthesis in the rainbow trout (Oncorhynchus mykiss) brain: modulation of tyrosine hydroxylase activity. Fish Physiology and Biochemistry 11 139-144.

Schulz RW, Bogerd J, Bosma PT, Peute J, Robers FEM, Zandberger MA \& Goos HJTh 1995 Physiological, morphological, and molecular aspects of gonadotropins in fish with special reference to the African catfish, Clarias gariepinus. In Reproductive Physiology of Fish, pp 2-6. Fish Symposium 95. The University of Texas at Austin. Eds FW Goetz \& P Thomas. Austin, USA.

Selmanoff M, Shu C, Hartman RD, Barraclough CA \& Petersen SL 1991 Tyrosine hydroxylase and POMC mRNA in the arcuate region are increased by castration and hyperprolactinemia. Molecular Brain Research 10 277-281.

Senthilkumaran B \& Joy KP 1994 Effects of ovariectomy and oestradiol replacement on hypothalamic serotonergic and monoamine oxidase activity in the catfish Heteropneustes fossilis: a study correlating plasma oestradiol and gonadotrophin levels. Journal of Endocrinology 142 193-203.

Senthilkumaran B \& Joy KP 1995 Changes in hypothalamic catecholamines, dopamine- $\beta$-hydroxylase, and phenylethanolamine-N-methyltransferase in the catfish, Heteropneustes fossilis in relation to season, raised photoperiod and temperature, ovariectomy and estradiol- $17 \beta$ replacement. General and Comparative Endocrinology 97 121-134.

Shiman R, Akino M \& Kaufman S 1971 Solubilization and partial purification of tyrosine hydroxylase from bovine adrenal medulla. Journal of Biological Chemistry 1330-1340.

Thomas P 1999 Nuclear and membrane steroid receptors and their functions in teleost gonads. In Proceedings of the 6th International Symposium on the Reproductive Physiology of Fish, pp 149-156. Eds B Norberg, OS Kjesbu, GL Taranger, E Andersson \& SO Stefansson. Bergen: Institute of Marine Research and University of Bergen.

Vetillard A, Bailhache T, Linard B, Saligaut C, Kah O \& Jego P 1999 Tyrosine hydroxylase expression in the preoptic area is regulated by a positive gonadal feedback in rainbow trout. In Proceedings of the 6th International Symposium on the Reproductive Physiology of Fish, pp 4-9. Eds B Norberg, OS Kjesbu, GL Taranger, E Andersson \& SO Stefansson. Bergen: Institute of Marine Research and University of Bergen.

Vom Saal FS, Timms BG, Montano MM, Palanza P, Thayer KA, Nagel SC, Dhar MD, Ganjam VK, Parmigiani S \& Welshons WV 1997 Prostate enlargement in mice due to fetal exposure to low doses of estradiol or diethylstilbestrol and opposite effects at high doses. PNAS 94 2056-2061.

Yamauchi T \& Fujisawa H 1978 A simple and sensitive fluorometric assay for tyrosine hydroxylase. Analytical Biochemistry 89 143-150.

Zigmond RE, Schwarzchild MA \& Rittenhouse AR 1989 Acute regulation of tyrosine hydroxylase by nerve activity and by neurotransmitters via phosphorylation. Annual Review of Neurosciences $12415-461$.

Received 16 July 2002

Accepted 22 July 2002 